\title{
Corporate Governance and Performance in Egyptian Listed Companies
}

\author{
Dr. Hanaa El-Habashy*
}

(*) Dr. Hanaa El-Habashy: She works as an Assistant Professor, University of Sharjah, Sharjah, UAE. She is a Lecturer in Accounting Department, Faculty of Commerce, Menoufia University, Egypt. She has got a PhD in Accounting, Dundee University, Scotland, UK. Her research interests are positive theory in accounting, contingency theory in accounting, corporate governments and performance evaluation.,

E-mail: helhabashy@ sharjah.ac.ae

hanaa82@hotmail.com 


\section{Abstract}

This paper aims to contribute the literature by examining the relation between corporate governance and performance in Egyptian listed companies, one of the emerging economies. Governance is measured as a multidimensional composite index comprised of board and ownership structure characteristics also the performance composite index comprised of ROA, ROE, and Tobin's Q. A sample of the most active non-financial companies the period 2009-2014, in which the final data has 240 firm-year observations was conducted to test the hypotheses. The results show that governance quality index has a high significant positive impact on firm performance index. Further, institutional ownership, private ownership, and ownership concentration have the strongest effects on all performance dimensions. Management ownership has an influence on accounting and market performance. The finding indicates a negative relation between board independence and performance. There might be factors/variables that affect the relation between corporate governance and performance that have not been identified in this study. Nevertheless, the specific factors/variables that used in this study have been used extensively in earlier studies. The results of this paper should be of interest to regulators, economists. Proponents of board independence should note with caution the negative relation between board independence and firm performance. Hence, if the purpose of board independence is to improve performance, then such efforts might be misguided. To the best of our knowledge, there is no study has yet empirically measure governance and performance as composite indexes in one of emerging economies, Egypt, or Middle Eastern countries.

يهدف هذا البحث إلى المساهمة في الأدبيات من خلال دراسة العلاقة بين حوكمة الثركات و الأداء

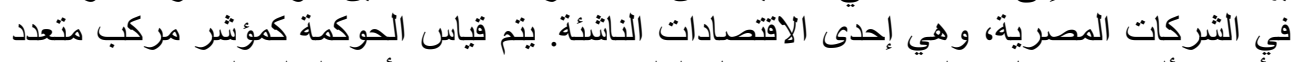

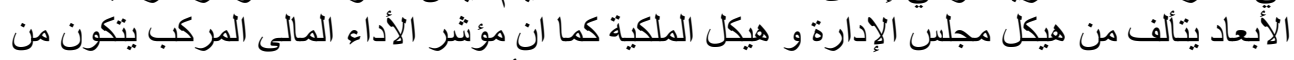

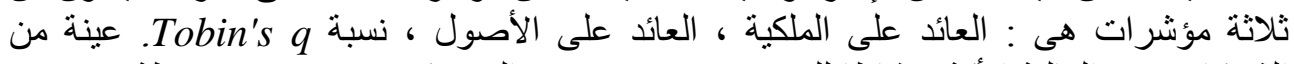

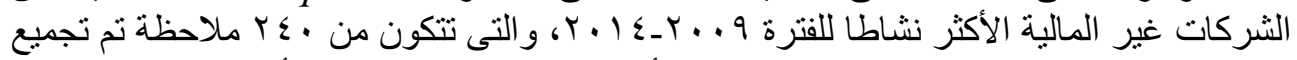

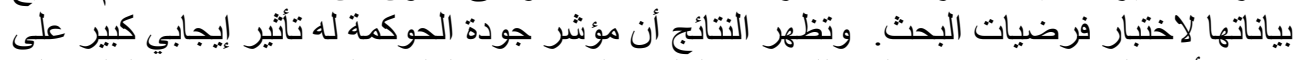

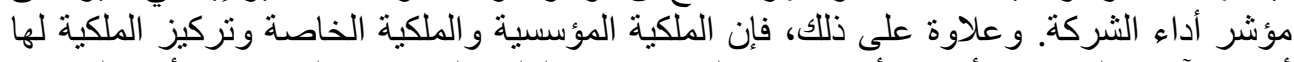

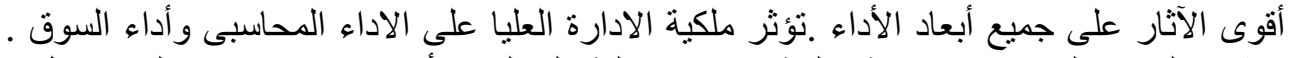

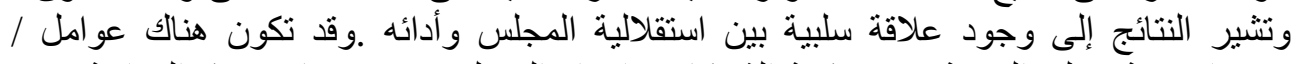

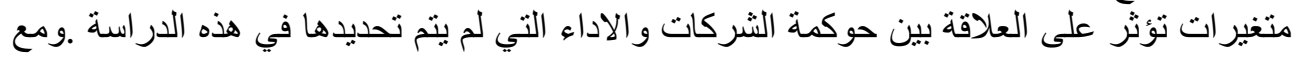




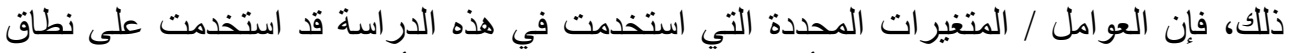

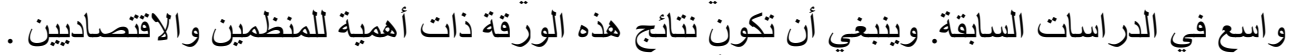

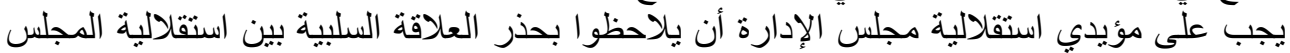

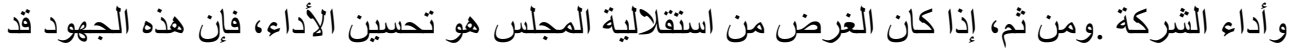

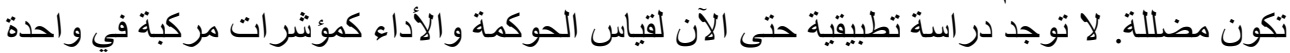
من الاقتصادات الناشئة، مصر ، أو بلدان الثرقة الأوسط.

\section{1- Introduction}

Corporate governance refers to the set of mechanisms that effect the decisions taken by managers when there is a separation between ownership and control. Some of these monitoring mechanisms are the board of directors, institutional shareholders, and the operations of the market for corporate control. The principle of corporate governance was first introduced by the Organization for Economic Co-operation and Development (OECD). The Reports on the Observation of the Standard and Codes (ROSC) made evaluations of corporate governance practices against these principles that are set by OECD. Egyptian Institute of Directors issued codes of corporate governance in 2005 and 2011. According to these codes, all listed companies are required to publish a report along with their annual reports to show their compliance with codes of corporate governance. The Egyptian Code of Corporate Governance (ECCG) adopted, perhaps, the most prominent principles of the (OECD) issued in 1999, and its amendments issued in 2004, as well as recent amendments which were made in 2015 and contain the six basic principles that represent reference of general corporate governance in the world. Compliance with the ECCG is mandatory for listed companies since the first issuance in 2005.

The literature classifies corporate governance mechanisms into external control mechanisms and internal control mechanisms. External control mechanisms are such as the stock market, market for corporate control (takeovers), and the competition in product markets (Macey and O'Hara, 2003). Internal control mechanisms are such as board of directors, monitoring by block-holders, compensation contracts, and managerial equity investment (Adams and Mehran, 2012; Macey and O'Hara, 2003). Brown and Caylor (2006) detect that firms with better governance quality as measured by the governance score are more profitable and have higher Tobin's Q. Their results recommend that firms with governance quality experience lower agency costs and, accordingly, display better performance and firm value. 
Most empirical research which studying the board structure-performance relationship utilizes data from the developed economies and gives mixed results. There is a related strand of the literature that considers corporate board characteristics as important determinants of corporate governance: board composition (Bhagat and Black, 2002), board size, Coles, et al., 2008; Cheng, 2008), and whether the Chairman and CEO positions are occupied by the same or two different individuals (Bai et al., 2012).

The relation between the ownership structure and corporate governance structure has been the core issue in the corporate governance literature. Shlefier and Vishny (1986), and Jensen and Meckling (1976) argue that ownership structure can reduce the agency costs since the ownership and control are separated. The empirical evidence on corporate governance suggests that large owners have a stronger incentive and better opportunities to exercise control over manager than small shareholders (Klapper and Love, 2002). Corporate governance exists to provide balances between shareholders and management and thus to mitigate agency problems. Hence, a firm's governance may influence firm performance by minimizing firmlevel agency conflicts and resulting agency costs.

This study examines the association between governance quality and performance by estimating multiple regression analysis to test this relation. Governance is measured in this study as a multidimensional composite index comprised of board and ownership structure characteristics. The composite index, GOV, represents the overall governance quality. The study measures performance through an integrated multi-level including return on assets "ROA", return on equity "ROE", and Tobin's Q. The composite index, PERF, represents the overall firm performance. This paper uses the disclosure book of the most active companies' data for governance and performance variables. In line with prior literature on the significant relation between board and ownership structures and firm performance, it is hypothesized that the firm performance is likely to be positively associated with the level of corporate governance quality. The contribution to the literature is a comprehensive and econometrically defensible analysis of the relation between corporate governance and performance in Egypt as an emerging country. Instead of considering just a single measure of governance, as prior studies in the literature have done, this study considers a composed index which includes seven different governance measures with three performance dimensions. Although the relation between corporate governance and firm performance has been the subject of extensive research 
in developed countries, limited research has been carried out to investigate the issue in the business environment of developing countries and even fewer such studies may be found in the Middle Eastern countries. Therefore, this study is aiming to answer the following research question:

Q1: - What drives the performance of Egyptian listed companies?

This study is particularly interested to know whether corporate governance affects the performance of firms listed in Egyptian Exchange market. The remainder of this paper is organized as follows. The next section discusses relevant literature to develop the research hypotheses. It is then followed by the research method outlining the sample and data sources, variables definition, and models specification. Findings and analysis are provided in the ensuing section. Finally, conclusions are offered in the last section.

\section{2- Literature Review and Hypothesis Development}

Prior research suggests firm characteristics and corporate governance mechanisms that potentially drive the corporate performance. Bhagat and Bolton, (2008); Brown and Caylor (2004), and Gompers, et al. (2003) report that board and ownership characteristics can be an effective measure of corporate governance. In this section, the study reviews relevant literature that investigates the relation between corporate performance and both ownership structure and board structure, as a proxy of corporate governance, to develop the hypotheses.

\subsection{Board Structure and Firm Performance}

The relationship between board structure and performance has been a continuing area of interest in the literature. From an organizational perspective, the board can be considered as a team brought together to work towards achieving organizational goals (Langton and Robbins, 2007). The better these activities are accomplished the more improvement in firm performance will be achieved. Board structure is represented by board size, CEO duality, and board composition.

2.1.1. Board Size: - Board size is the most expanded board structure in the corporate finance literature as in general the relationship between board size and corporate performance is found to be inversely correlated. Jensen (1993); Yermack (1996); Eisenberg et al (1998) and Cheng (2008) confirm a negative relationship between board size and firm value as benefits of monitoring from enlarging boards are faced with problems related to 
increased asymmetric information and confused communication issues. Larger board size may lead to problems in group coordination and effectiveness in arriving at decisions (Jensen, 1993). On the contrary, Coles, et al. (2008) realize that there is a positive relationship between the board size and corporate performance. Their findings are consistent with the resource dependence theory which suggests that larger board size would lead to better corporate performance because of the different skills, knowledge, and expertise. In addition, Dehaene et al. (2001) and Chin et al. (2004) did not find a significant association between board size and corporate performance. As the majority of the prior literature appears to suggest a negative relationship between board size and corporate performance, it is assumed that companies with smaller board size perform better than others.

2.1.2. CEO Duality: - The governance code recommends that the positions of chairman and CEO be held by two different people to ensure a balance of power and authority. It refers to a situation where the firm's CEO also serves as chairman of the board of directors. CEO/Chair duality is an important board control structure mechanism. The argument against role duality stems from the notion that directors are entrusted with monitoring and evaluating the actions of top management, combining the roles would mean evaluating one's own performance (Rhoades et al., 2001). There are two competing views about $\mathrm{CEO} /$ Chair duality based on the perception of whether a firm is best served by strong leadership (stewardship theory), or by monitoring effectively (agency theory). Jensen (1993); Rechner and Dalton (1991); and Fama and Jensen (1983) support separation of the CEO and Chair positions because of duality would reduce a board's supervision of the management of a company. This reduction results in an increase of the agency costs. Based on this argument, separating the roles of chairman and CEO should lead to better corporate decisions and hence performance. Empirical evidence on the relationship between role duality and corporate performance is mixed. Bai et al. (2012) report that companies in which the CEO was also the chairman or vice chairman of the board of directors, these companies were significantly lower valued in Asian firms. A negative relationship between CEO duality and corporate performance was also documented in Hong Kong (Chen et al., 2005). In contrast, role duality was found to be significant and positively associated with corporate performance in Belgian companies when measured by ROA (Dehaene et al., 2001). 
Leighton and Thain (1993) indicate that the effectiveness of the board is largely decided and dependent on the impact of this position. If the person holds both the positions of CEO and the chair he/she is expected to focus on achieving the goals and providing strong leadership to the firm. However, CEO duality broadens the chair power base and weakens the board's role of monitoring and evaluating performance of the top management as the director of the same company has close relations with the management (Coles and Hesterly, 2000). According to organization theory, CEO duality establishes strong unambiguous leadership (Finkelstein and D'Aveni 1994). According to agency theory, CEO duality induces the chair to reduce board monitoring effectiveness. When the CEO is also the chairperson of the board, board 's capacity to monitor the CEO is even further diminished. It has been argued that boards adopting CEO duality leadership are less likely to dissent board decisions (Mallette and Fowler, 1992). It considers boards in which the separation of the positions of chair and CEO, to be independent, declines the CEO's authority and increases the board's ability to perform its oversight role effectively (Boyd, 1995). However, mere separation may not be a clear indication of the independence of the board. Hermalin and Weisbach (2003) recommend that board independence depends on the CEO's bargaining position which is derived effectively from his/her perceived ability. This paper considers CEO/Chair duality as a proxy for how much independence the chairman. Thus, this study adopts the literature viewpoint that emphasizes the positive relationship between the absence of CEO/chair duality and firm performance.

2.1.3. Board Composition: - The governance code recommends that, at least one third of the board as a whole should be non-executive directors, most of whom should be independent. The literature has used many different theoretical perspectives to evaluate the effect of board characteristics on firm performance. The common aim of different theories has been to establish a link between various board characteristics and firm performance (Kiel and Nicholson, 2003). Monitoring mechanisms often involve the selection of socio-politically independent boards. Agency theory emphasizes the importance of board independence as a prerequisite for its effectiveness controlling and monitoring functions over management (e.g., Eisenhardt, 1989; Fama and Jensen, 1983). According to agency theory, absence of effective control systems is likely to induce managers to pursue opportunistic behavior to maximize their own utility rather than shareholder 
wealth maximization. Early researchers (Mace, 1971; Norburn and Grinyer, 1974) argued that boards inspire little contribution to strategy and the role of strategy making is performed mainly by the chief executive. Whereas, dominance of inside executives on the board may lead the board to be less effective in controlling the CEO because they are hierarchically under authority of the CEO. Firm governance structure and the board composition are viewed as a resource that can add value to the firm (Daft, 2006). An argument of the resource dependence theory is that organizations attempt to exert control over their environment by co-opting the resources needed to survive (Pfeffer and Salancik, 1978). Consequently, boards are considered as a link between the firm and the essential resources that a firm need from the external environment for superior performance. Appointment of outsiders on the board helps in gaining access to resources critical to firm success and manage environment contingency (Johnson et al., 1996). Hermalin and Weishbach (2003) detect poor financial and stock market performance of a firm often leads to appointment of financial directors to the board. Further, Pearce and Zahra (1992) found that outsiders are appointed on the board in order to bring a fresh perspective when the firm is not doing well. Higher board independence should enable a more objective and thorough supervision then impact the share of directors on corporate performance.

Based on previous literature and the above-mentioned arguments, this study assumes a positive association between board structure and firm performance, therefore, the first hypothesis is formulated as follows:

Hypothesis 1: - Board structure is positively associated with firm performance in Egypt.

\subsection{Ownership Structure and Firm Performance}

There is a related strand of the literature that considers the impact of ownership structure on performance. The benefits and costs of ownership concentration have been widely discussed since Berle and Means (1932) argue that widely dispersed ownership reduces the effective power of shareholders to control the management of the corporation. Most research has followed Demsetz and Lehn (1985) in measuring concentration with respect to a group of owners, usually as the total equity share owned by the largest five or largest 20 investors. In the same context, Levine (2004) argues that concentrated ownership is a governance mechanism that prevents managers from deviating from shareholder interests as large 
shareholders have more incentive to acquire information and monitor managers than small shareholders. Ownership structure is represented by concentrated ownership, managerial ownership, private-firms' ownership, and institutional ownership.

2.2.1. Ownership Concentration: - Ownership concentration is a key corporate governance mechanism that helps to limit agency problems arising from the separation of ownership and control (Shleifer and Vishny, 1986), which, in turn, leads to improved performance (Jensen and Meckling, 1976). As owning a large proportion of shares, controlling shareholders have strong incentives to actively monitor and real power to discipline and/or influence management (Shleifer and Vishny, 1986). Other discussions about the possibility that concentrated ownership exercise their control rights to create private benefits against smaller investors. As highly concentrated ownership is likely to change the agency problem from traditional principal-agent conflict to principal-principal conflicts (Bebchuk and Weisbach, 2010). Mostly, where external corporate governance mechanisms are underdeveloped, the monitoring effect of ownership concentration is even more important (Filatotchev et al., 2013). Whereas when a company performs poorly, large shareholders may reduce the size of their concentrated owner's stake to achieve more diverse personal portfolios (Yabei and Izumida, 2008). Under agency models, managers may have incentives to make decisions that are in their interest, but not necessarily in shareholders' best interests (Capozza and Seguin, 2002). Accordingly, shareholders will take actions to mitigate the potential for such costs since these may reduce the value of the firm. Therefore, where possible they will pursue to control the managers.

In general, prior literature about the relationship between ownership concentration and firm performance have produced mixed results. While, Pham et al. (2011) and Schultz et al. (2010) found insignificant relationship for the Australian market, the relationship is significant for the Japanese market (Yabei and Izumida, 2008) and for the Singapore and Vietnamese markets (Nguyen, et al, 2015). This paper expects a positive relationship between concentration ownership and firm performance.

2.2.2. Managerial Ownership: - Managerial ownership refers to the ownership stake in a company that is held by the top management. Jensen and Meckling (1976) suggest that managerial ownership enable to alleviate 
agency conflicts between managers and owners, as a manager who holds a large portion of the company stock has more incentives to maximize job performance to ensure better company performance. Toal and Ruenzi (2014) examined the relationship between director ownership and stock market performance, they indicate that director ownership can reverse the negative impact of weak governance, as they reduce empire building and run their firms more efficiently. Ownership by the manager may be used to induce managers to act in a manner that is consistent with the interest of shareholders (Grossman and Hart, 1983). Consistent with this view, Kim and $\mathrm{Lu}$ (2011)'s study showed the relation between director ownership and firm valuation hinges critically on the strength of external governance, as director ownership and external governance are substitutes for mitigating agency problems when ownership is low. However, Kim and Lu (2011); Chiang (2005); Daily and Dalton (2004); Han and Suk (1998); and Agrawal and Knoeber (1996) found that an increase in managerial ownership led to better corporate performance, however, very high levels of share ownership resulted in worse corporate performance by entrenching the director and discouraging him from taking risks, unless mitigated by strong external governance. As the prior literature appears, this paper expects a positive relationship between managerial ownership and the firm's performance.

2.2.3. Private-Firm Ownership: - Private-firm ownership refers to the ownership stake in a company that is held by private-firms. The majority of Egyptian firms are primarily owned by relatively small numbers of shareholders or families. The ownership required to call shareholders' meetings is $5 \%$ for ordinary meetings and $10 \%$ for extraordinary meetings. In addition, the private companies' block holders have the right to have a representative in the board. That situation suggests that owners will frequently be clearly involved in monitoring and evaluating the actions of top management for better performance.

The agency theory in the work of Fama and Jensen (1983) and Fama (1980) is not as strict or as profit oriented as in privately-owned companies. Dewenter and Malatesta (2001) and Ahuja and Majumdar (1998) Farinos et al. (2007) recognize that privately-owned firms are significantly more profitable than governmental companies. However, privately-owned firms occasionally, pose inferior efficiency output than government-owned ones. Omran (2004) reveal that Egyptian privatized firms do not exhibit significant improvements in performance compared with state-linked 
corporations. Similar results, but for different reasons, are exhibited by studies in highly developed economies. Kole and Mulherin (1997) found that in the U.S., corporations where the government owned an interest (between 35-100\%) showed performance not statistically different than that of private sector firms in the same industry. They attribute their results to the existence of similar monitoring mechanisms the government-owned corporations to that of private firms' blockholders. It is clear that, there is no consensus in the literature about the relationship between private sector ownership and performance compared with other types of corporations. Often, the privately-owned companies converted to be the dominant and enable them to pressure managers for better performance. Subsequently, the study expects a positive relationship between private ownership and the firm's performance. The percentage of a company's shares that are held by private firms is used as a proxy of private firm ownership.

2.2.4. Institutional Ownership: - Institutional ownership refers to the ownership stake in a company that is held by governmental organizations, insurance companies, commercial banks, hedge funds, and mutual funds that invest money for wealthy clients. Institutions generally purchase large blocks of a company's outstanding shares and can exert considerable influence upon its management. Previous literature has focused on the role of institutional owners as corporate monitors. Smith (1996); and Del Guercio and Hawkins (1999) found evidence compatible with the hypothesis that corporate monitoring by institutional owners can force managers to focus more on corporate performance and less on opportunistic or self-interest behavior. Nevertheless, the impact of institutional owners on corporate decisions is affected by the size of their shareholdings (Maug, 1998). If institutional owner's shareholdings are high, hence, there is more incentive to monitor a firm's management. Vice versa, when institutional owners hold relatively few shares in a firm, they have less incentive to monitor. According to the impact of institutional ownership on firm performance, Smith (1996) found a positive association between institutional ownership and firm performance measures. Institutional investors' ownership of large block of shares in large corporations enables them to pressure managers for better performance as good corporate governance is a function of large shareholding and effective legal protection, (La Porta et al., 1997). Lakshmi (2009); and Jensen (1986) argued that institutional investors can decrease the agency costs by the close 
monitoring of the corporate performance and by ensuring the shareholders' interests. In addition, Shleifer and Vishny (1986) prove that institutional investors effectively monitor managers' performance. Institutional investors' ownership of large blocks enables them to pressure managers for better performance as good corporate governance is a function of large shareholding and effective legal protection. This study expects a positive relationship between institutional ownership and the firm's performance, it is assumed that companies with high institutional ownership perform better than others.

It seems more interesting to explore the link between the corporate ownership and its identity with performance. Based on the conflicted predictions of agency theory and the above-mentioned arguments, this study proposes a positive significant link between ownership structure and performance. The second hypothesis is formulated as follows:

Hypothesis 2: - Ownership structure is significantly associated with firm performance in Egypt.

Based on the review of previous literature on the significant relation between board and ownership structures and firm performance, this study assume that firm performance will be positively affected by the quality of governance therefore, this study can formulate the main hypothesis as follows:

Hypothesis3: - Corporate governance is significantly associated with firm performance in Egypt.

\section{3- Research Methodology}

Instead of considering just a single measure of governance, this study considers seven different governance measures. Evidence from previous empirical studies from academic literature has sought to confirm the effect of corporate governance on a firm's performance. A literature review from relevant academic studies has indicated the following characteristics applied to corporate governance such as ownership and board structures. To test the hypotheses that developed for the study, this study creates three OLS regression models. In this section, this study discusses sample and data sources, variables definition, and model specification.

\subsection{Sample and Data Sources: -}

This study uses data of most active companies in the Egyptian Stock Market covering the different sectors of companies provided by the 
Disclosure Book issued by the Egyptian Exchange (EGX) in Cairo. As corporate governance became one of the main distinctive rules that benchmark the sustainability and growth of companies, disclosure practices arise as one of the main objectives of the Egyptian Exchange for the purpose of market transparency and integrity. The disclosure book provides consolidated information about the company, including basic information, board of directors, shareholding structure, latest three-year financial figures and ratios as well as the latest corporate actions and material events for each company.

The data spans the period from 2009-2014 because of the availability of data. The year 2009 was chosen as the beginning of the analysis period. In line with previous studies (Farooqi et al., 2014; Lien and Li, 2013; Yu, 2013; Bae et al., 2012; and Lemmon and Lins, 2003), data on financial firms (banks, securities companies, and insurance companies) is not included because these firms are completely different from non-financial firms (Lin and Shiu, 2003), and some variables may not be comparable between financial and other firms (Liljeblom and Löflund, 2005). The choice of firms was based on the availability of data. The study uses the disclosure book of the most active companies' data for performance and governance variables. The banking and insurance sectors were excluded, consequently, only corporate annual reports of the most active non-financial firms were collected. The sample includes firms which are dissimilar in size, and sector. Hence, the final data has 240 firm-years observations.

\subsection{Variables Definition: -}

\subsubsection{Performance Variables: -}

Three ratios to measure firm performance were calculated namely return-onassets (ROA), return on equity (ROE), and Tobin's Q. While the ROE and ROA are employed as measures representing accounting performance measures, Tobin's Q is used to measure the market performance of firms. The composite index, PERF, represents the overall firm performance. Multi predictive value for firm performance (PERF) was computed using standardized value as variables of performance then compute the target variable of PERF as a composite index. This study uses data being disclosed in the financial statements for calculating return-on-assets "ROA", returnon- Equity "ROE", and Tobin's Q. ROA calculated as net profit after tax divided by total assets, (Barber and Lyon, 1996). According to Damodaran (2007), this study calculates ROE as net profit after tax divided by 
shareholders' equity. Similar to Gompers et al. (2003), Tobin's Q calculated as (total assets + market value of equity - book value of equity deferred taxes) divided by total assets. Codes and measurements of the used variables are summarized in Table (1).

Table 1: - Description of variables

\begin{tabular}{|c|c|c|c|c|}
\hline Variable & Definition & \multicolumn{2}{|c|}{$\begin{array}{l}\text { Composite } \\
\text { index }\end{array}$} & Measurement \\
\hline \multicolumn{5}{|c|}{ Independent variables:- Governance variables } \\
\hline$B S I Z E$ & Board Size & \multirow{3}{*}{$\underset{\infty}{\infty}$} & \multirow{7}{*}{ ठ } & The total number of directors \\
\hline BINDEP & $\begin{array}{l}\text { Board } \\
\text { Independence }\end{array}$ & & & $\begin{array}{l}\text { Percentage of non-executive directors } \\
\text { on the board } \%\end{array}$ \\
\hline Dual & $\begin{array}{l}\text { Absence of } \\
\text { CEO/Chair } \\
\text { Duality }\end{array}$ & & & $\begin{array}{l}\text { A dummy variable equal to } 0 \text { if the } \\
\text { CEO is also the chairman of the board } \\
\text { and } 1 \text { otherwise. }\end{array}$ \\
\hline INST & $\begin{array}{l}\text { Institutional } \\
\text { Ownership }\end{array}$ & \multirow{4}{*}{$\sum_{0}^{\infty}$} & & $\begin{array}{l}\text { Percentage of shares held by held by } \\
\text { institutional shareholders, including the } \\
\text { Egyptian government } \%\end{array}$ \\
\hline OWCO & $\begin{array}{l}\text { Ownership } \\
\text { Concentration }\end{array}$ & & & $\begin{array}{l}\text { Percentage of shares held by the } \\
\text { largest shareholders } \%\end{array}$ \\
\hline PRIV & $\begin{array}{l}\text { Private-firms } \\
\text { Ownership }\end{array}$ & & & $\begin{array}{l}\text { Percentage of shares held by private } \\
\text { firms } \%\end{array}$ \\
\hline ManOwn & $\begin{array}{l}\text { Managerial } \\
\text { Ownership }\end{array}$ & & & $\begin{array}{l}\text { Percentage of the firm's stock owned } \\
\text { by the top management } \%\end{array}$ \\
\hline \multicolumn{5}{|c|}{ Dependent variables:- Performance variables } \\
\hline$R O A$ & $\begin{array}{l}\text { Return on } \\
\text { Assets }\end{array}$ & \multirow{3}{*}{\multicolumn{2}{|c|}{ PERF }} & $\begin{array}{l}\text { Measured as net profit after Tax / total } \\
\text { assets }\end{array}$ \\
\hline$R O E$ & $\begin{array}{l}\text { Return on } \\
\text { Equity }\end{array}$ & & & $\begin{array}{l}\text { Measured as net profit after tax / } \\
\text { shareholders' equity }\end{array}$ \\
\hline Tobin's $Q$ & $\begin{array}{l}\text { Market } \\
\text { Performance }\end{array}$ & & & $\begin{array}{l}\text { Measured as (total assets }+ \text { market } \\
\text { value of equity - book value of equity } \\
\text { - deferred taxes) / total assets. }\end{array}$ \\
\hline \multicolumn{5}{|c|}{ Control variables } \\
\hline$C A$ & $\begin{array}{l}\text { Capital } \\
\text { Adequacy }\end{array}$ & & & $\begin{array}{l}\text { Book value of equity to total assets } \\
\text { ratios }\end{array}$ \\
\hline$L E V$ & Leverage & & & Debt to total assets ratios \\
\hline$D B E Q$ & $\begin{array}{l}\text { Debt to } \\
\text { Equity }\end{array}$ & & & Long-term debt to equity ratios \\
\hline SIZE & Firm Size & & & Total Assets \\
\hline
\end{tabular}




\subsubsection{Corporate Governance Quality Variables: - \\ Board Variables}

Regarding the board variables, data on board size, board independence, and CEO-Chair duality obtained from EGX. The variables of board structure are the total number of directors (BSIZE), the percentage of non-executive directors on the board (BINDEP), and CEO/Chair Duality (Dual). Dual measured as a dummy variable equal to 0 if the CEO is also the chairman of the board and 1 otherwise. Multi predictive value for board structure (BOARD) was achieved using standardized values as variables of ownership structure then computing the target variable of BOARD as a composite index.

\section{Ownership Concentration Variables}

The measures of ownership structure are the percentage of shares held of large block (OWCO), the fraction owned by Institutional shareholders including the Egyptian government (INST), the fraction owned by the top management (ManOwn), and the fraction owned by private companies (PRIV). Multi predictive value for ownership structure (OWNER) was achieved using standardized value as variables of ownership structure then compute the target variable of OWNER as composite index. The study focuses on the impact on the percentage of their holdings in the company rather than on the dollar value ownership. Data on ownership structure obtained from EGX.

\section{Control Variables}

Factors other than ownership and board structures may also affect a firm's performance. To take them into account, this study introduces a set of control variables. Kayhan and Titman (2007) found a negative association between performance and the debt-to-equity ratio. Furthermore, the literature indicate a negative relationship between firm size and firm performance as large firms are more likely to finance their activities using debt than smaller firms (Al-Najjar and Hussainey, 2009) and not compelled to choose the accounting method to increase earnings. On the basis of data being disclosed in the financial statements, leverage computed as the firm's debt to total assets and long-term debt to equity ratios. While the ratios of debt to total assets ratios were calculated (LEV), the ratios of long-term debt to equity ratios (DBEQ) were available for all companies. The value of total assets (SIZE) is used to control size effect (see e.g. McConnell and Servaes, 1990). The literature argues that the capital adequacy variable (CA) has a positive effect on performance (Goddard et al., 2004). The capital adequacy 
variable measured as capital divided by total assets and this study expects it to have a positive relation to performance.

\subsection{Model Specification}

To test the first hypothesis (H1), this study creates a multivariate crosssectional model that tests the impact of board structure BOARD on performance. The main independent variable BOARD which has been defined as a multidimensional composite index. The control variables are added to the model to determine their importance in determining performance. The primary analysis involves an examination of the significance of the coefficient of the primary variable BOARD.

Model 1: firm performance $=f$ (Board structure, Control variables) PERFit (performance) $=\beta_{0}+\beta_{1}$ BOARDit $+\beta_{2}$ CAit $+\beta_{3}$ LEVit $+\beta_{4}$ DBEQit $+\beta 5$ SIZEit + ejt ...... (Model 1)

Similarly, to test the study hypothesis (H2), this study creates a multivariate cross-sectional model that tests the impact of ownership structure OWNER on performance. The main independent variable $O W N E R$ has been defined as a multidimensional composite index.

Model 2: firm performance $=f$ (Ownership structure, Control variables) PERF it (performance) $=\beta_{0}+\beta_{1}$ OWNER it $+\beta_{2} C A$ it $+\beta_{3} L E V$ it $+\beta_{4}$

$D B E Q$ it $+\beta_{5}$ SIZE it + ejt ...... (Model 2)

To test the main study hypothesis (H3), this study creates a multivariate cross-sectional model that tests the impact of firm quality corporate governance on performance. The main independent variable firm governance quality, $G O V$, has been defined as a multidimensional composite index generated by factor analysis of the board structure variables and ownership structure variables. This study estimates an OLS regression model using PERF as the dependent variable in the Model 3, and GOV is the explanatory variable. The control variables are added to the model to determine their importance in determining performance. The primary analysis involves an examination of the significance of the coefficient of the variable $G O V$.

Model 3: firm performance $=f$ (Governance quality, Control variables) PERF it (performance) $=\beta_{0}+\beta_{1} G O V$ it $+\beta_{2} C A$ it $+\beta_{3} L E V i t+\beta_{4} D B E Q$ $i t+\beta_{5}$ SIZE it + ejt ...... (Model 3) 
Variable definitions are shown in Table (1). Coefficient $\beta 1$ represents the coefficient estimate for the corporate governance quality composite index score testing the hypothesized relationship, while $\beta 2$ through $\beta 5$ represent the coefficient estimates for the control variables suggested by prior literature as determinants of performance. eit $=$ error term.

Aside from analyzing the relation between PERF and GOV, The effect of governance index components on performance components is examined in a separate model as indicated in Model 3(a).

PERF it (performance) $=\beta_{0}+\beta_{1}$ BSIZE it $+\beta_{2}$ BINDEP it $+\beta_{3}$ Dual it $+\beta_{4}$ OWCO it $+\beta_{5}$ ManOwn it $+\beta_{6}$ INST it $+\beta_{7}$ PRIV it $+\beta_{8} C A$ it $+\beta_{9} L E V$ it $+\beta_{10} D B E Q$ it $+\beta_{11}$ SIZE it + ejt....... (Model 3a)

Furthermore, models $3(\mathrm{~b}-\mathrm{d})$ are developed to examine the impact of individual firm governance components (BSIZE, BINDEP, Dual, OWCO, ManOwn, INST, and PRIV) on each of the three performance dimensions explored in this study: ROA, ROE, and Tobin's Q. The objective is to explore the governance component that drives specific performance dimensions.

ROA it (performance) $=\beta_{0}+\beta_{1}$ BSIZE $+\beta_{2}$ BINDEP it $+\beta_{3}$ Dual it $+\beta_{4}$ OWCO it $+\beta_{5}$ ManOwn it $+\beta_{6}$ INST it $+\beta_{7}$ PRIV it $+\beta_{8} C A$ it $+\beta_{9}$ LEV it $+\beta_{10} D B E Q$ it $+\beta_{11}$ SIZE it + ejt ....... (Model 3b)

$\mathrm{ROE}$ it (performance) $=\beta_{0}+\beta_{1}$ BSIZE $+\beta_{2}$ BINDEP it $+\beta_{3}$ Dual it $+\beta_{4}$ OWCO it $+\beta_{5}$ ManOwn it $+\beta_{6}$ INST it $+\beta_{7}$ PRIV it $+\beta_{8}$ CA it $+\beta_{9}$ LEV it $+\beta_{10} D B E Q$ it $+\beta_{11}$ SIZE it + ejt ....... (Model 3c)

Tobin's $Q$ it (performance) $=\beta_{0}+\beta_{1}$ BSIZE $+\beta_{2}$ BINDEP it $+\beta_{3}$ Dual it + $\beta_{4}$ OWCO it $+\beta_{5}$ INST it $+\beta_{6}$ ManOwn it $+\beta_{7}$ PRIV it $+\beta_{8} C A$ it $+\beta_{9} L E V$ $i t+\beta_{10} D B E Q$ it $+\beta_{11}$ SIZE it + ejt $\ldots \ldots .$. (Model 3d)

In models $3(\mathrm{a}-\mathrm{d})$, coefficients $\beta_{1}$ through $\beta_{7}$ represent the coefficient estimate for the corporate governance quality testing the hypothesized relationship, while $\beta_{8}$ through $\beta_{11}$ represent the coefficient estimates for the control variables suggested by prior literature as determinants of performance.

\section{4- Empirical Results}

\subsection{Descriptive Statistics}

Table (2) reports the mean, median, standard deviation, minimum, and maximum for the continuous variables in the sample data of this study. It 
shows the mean GOV as a composite index and governance components. The average firm is characterized by the following mean values: board size of 10.72 members, non-executives representing 0.83 of the board, and separation of CEO/Chairman positions of 0.23 . On the ownership side, the institutional investor ratio ranges from 0 to 0.92 with a mean of about 0.21 and a standard deviation of 0.28. Taking the average, it seems that Egyptian listed firms having reasonable percentage of institutional investors. The mean of largest block-holder ownership ratio ranges from 0.1 to 0.92 with a mean of 0.38 . Private ownership ratio ranges from 0 to 0.88 with a mean of 0.30 and a standard deviation of 0.24 . This indicates that private investors participate less in the ownership of Egyptian firms than institutional investors.

Table 2: - Descriptive Statistics $(n=240)$

\begin{tabular}{|l|c|c|c|c|c|}
\hline & Mean & Median & $\begin{array}{c}\text { Std. } \\
\text { Deviation }\end{array}$ & Min & Max \\
\hline PERF & 0.23 & 0.20 & 0.22 & -0.20 & 0.83 \\
\hline GOV & 0 & -0.34 & 2.33 & -3.81 & 4.30 \\
\hline BOARD & 0 & .17 & 1.91 & -3.98 & 3.18 \\
\hline OWNER & 0 & .12 & 1.56 & -3.71 & 3.35 \\
\hline BSIZE & 10.72 & 11.00 & 3.74 & 5 & 21 \\
\hline BINDEP & 0.83 & 0.89 & 0.13 & 0.44 & 1 \\
\hline Dual & 0.23 & 0.00 & 0.42 & 0 & 1 \\
\hline OWCO & 0.38 & 0.33 & 0.23 & 0.00 & 0.92 \\
\hline ManOwn & 0.07 & 0.00 & 0.14 & 0.00 & 0.66 \\
\hline INST & 0.21 & 0.06 & 0.28 & 0.00 & 0.92 \\
\hline PRIV & 0.30 & 0.36 & 0.24 & 0.00 & 0.88 \\
\hline ROA & 0.07 & 0.06 & 0.08 & -0.10 & 0.34 \\
\hline ROE & 0.14 & 0.12 & 0.15 & -0.11 & 0.68 \\
\hline Tobin's Q & 0.01 & 0.01 & 0.01 & 0.00 & 0.05 \\
\hline DBEQ & 0.00 & 0.00 & 0.01 & 0.00 & 0.04 \\
\hline CA & 0.01 & 0.01 & 0.00 & 0.00 & 0.04 \\
\hline SIZE & 32078.19 & 2183 & 184649.32 & 125 & 1454244 \\
\hline LEV & 0.001 & 0.000 & 0.001 & 0.000 & 0.007 \\
\hline
\end{tabular}




\begin{tabular}{|c|c|c|c|c|c|c|c|c|c|c|c|c|c|c|c|c|c|}
\hline 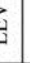 & & & & & & & & & & & & & & & & & \\
\hline 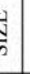 & & & & & & & & & & & & & & & & & \\
\hline 5 & & & & & & & & & & & & & & & & & - \\
\hline 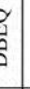 & & & & & & & & & & & & & & & & $-\cdot$ & . \\
\hline & & & & & & & & & & & & & & & $-\cdots$ & 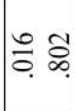 & $\frac{\infty}{7}$ \\
\hline 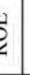 & & & & & & & & & & & & & & $-\cdot$ & f̦ & 告 & $\stackrel{0}{\circ}$ \\
\hline 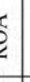 & & & & & & & & & & & & & $-\cdot$ & : : & ) ৪. & $\frac{\infty}{1}$ & $\widehat{\exists}$ \\
\hline 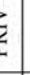 & & & & & & & & & & & & -1 & 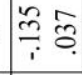 & $\mp 8$ & $\frac{8}{1}$ & ఫ. \&. & ș \\
\hline 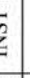 & & & & & & & & & & &.- & స్తి & ֻ & . & స్ ঃ & 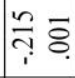 & కై \\
\hline 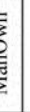 & & & & & & & & & & - & $\frac{2}{9}$ & $\frac{\infty}{\infty} \div$ & 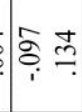 & $\stackrel{0}{\circ}$ & $\frac{\sigma}{O}=$ & 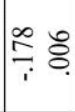 & క. \\
\hline 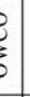 & & & & & & & & & - . & $\mid \begin{array}{ll}\infty & 0 \\
0 & 0 \\
i & 0\end{array}$ & ธิ & $\frac{0}{0}$ & ?. & $\bar{\delta}$ & 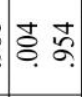 & $\stackrel{\circ}{\varrho}$ & $\stackrel{\leftrightarrow}{c}$ \\
\hline 5 & & & & & & & & $-\cdot$ & g. & 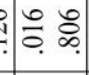 & ?. & సे ః : & 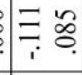 & ఫे & $\overrightarrow{\underline{o}} \bar{i}$ & 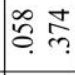 & $\stackrel{t}{t}$ \\
\hline 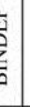 & & & & & & & - & 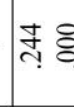 & ?ִ & : & 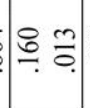 & ণั) & 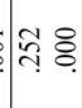 & $\sum_{i}^{\infty} \underset{\infty}{\infty}$ & 岕 & $\underset{7}{7}$ & $\Xi$ \\
\hline 6 & & & & & & - & $\aleph_{\curvearrowright}$ & ?ִ & †े & 5 & $\stackrel{\infty}{\infty}$ & ?ి & 潁 & $\frac{m}{m}$ & ક & $\frac{\pi}{7} \frac{2}{0}$ & 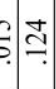 \\
\hline 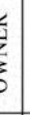 & & & & & - & : & ?ุ & $\exists$ & b. & $\frac{n}{m}$ & 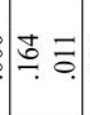 & તે ః & . & $\ddot{g}$ & 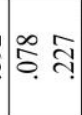 & & $=$ \\
\hline 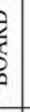 & & & - & & $\overbrace{i}^{\infty} \stackrel{\infty}{\circ}$ & . & $\infty_{\infty}^{\infty}$ & 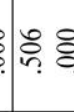 & 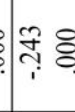 & के & $\stackrel{5}{0}$ & $\frac{8}{1} \mathrm{I}$ & 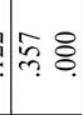 & 苾 & $\bar{\delta} \bar{\sigma}$ & $\cong$ & 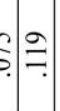 \\
\hline$b$ & & - & & ఫे. & 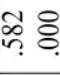 & †. & bे & לे ঃे & 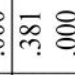 & त़ & ำ & 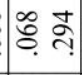 & \% \& & 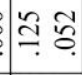 & $\begin{array}{ll}\infty \\
0 \\
0\end{array}$ & 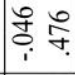 & t. \\
\hline 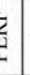 & _ & ণิ่ & & 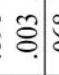 & 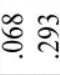 & $\frac{n}{7} 8$ & 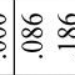 & $\hat{n}_{1}$ & $\int_{i}^{0} \frac{\infty}{7}$ & 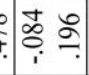 & ồ o & $\frac{5}{1} \div$ & 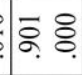 & \% : & to \& & 궁 & కి \\
\hline & 崖 & 己े & & 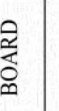 & 鰙 & 岂 & 商 & 嵒 & \& & $\begin{array}{l}\text { ह } \\
\text { Dे } \\
\text { हू }\end{array}$ & $\bar{n}$ & $\gtreqless$ & $\stackrel{\overleftarrow{a}}{\approx}$ & : & 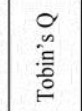 & 哭 & 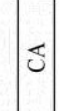 \\
\hline
\end{tabular}


Further, top management ownership ratio ranges from 0 to 0.66 with a mean of 0.07 and a standard deviation of 0.14 . In terms of performance, well governed firms have on average a higher performance index (PERF) score driven by higher financial and accounting performance (ROA), (ROE), and Tobin's Q. PERF ranges from -0.02 to 0.83 with a mean of 0.23 and a standard deviation of 0.22 . According to the accounting performance, ROA ranges from -0.10 to 0.34 with a mean of 0.07 as well ROE ranges from 0.11 to 0.68 with a mean of 0.14 . Furthermore, Tobin's Q ranges from 0to 0.05 with a mean of 0.01 . Taking the average, it seems that accounting performance indicators are higher than market performance indicator in Egyptian firms. The table also provides some information about the characteristics of the sample.

Regarding control variables, the table provides some information about debt to equity, which ranges from 0 to 0.04 and has mean and standard deviation of 0 . This indicates that Egyptian firms, on average, do not have high gearing. Firm size (logarithm of total assets) ranges from 125 million to about 1454 billion with a mean of 32 billion Egyptian pound. As for firm characteristics, well-governed firms have smaller size, higher capital adequacy, lower debt to equity, and lower leverage.

\subsection{Correlation}

Table (3) shows the correlations matrix between performance, governance, and other control variables. Pearson correlation coefficients are above and the p-values are below. PERF is significantly positively correlated with GOV and BOARD, lending initial support to the study hypotheses (H1) and (H3). However, PERF is insignificantly correlated with OWNER, lending initial rejection of the second study hypothesis (H2). According to GOV component, while, PERF is significantly negatively correlated with Dual, PRIV, DBEQ, SIZE, and LEV it is significantly positively correlated with BSIZE and INST. The table shows that, PERF is not correlated with BINDEP, OWCO, ManOwn, and CA. It also presents the correlation between performance variables (ROA, ROE, and Tobin's Q) and the correlation between governance variables (BSIZE, BINDEP, Dual, OWCO, ManOwn, INST, and PRIV). The table shows that, institutional ownership is correlated with leverage and debt to equity. The interpretation of the correlation as institutional ownership has a material impact on critical corporate decisions such as capital structure choices (Jiraporn, et al. 2012).

\subsection{Regression Analysis and Discussion}

The results of the regression analysis of the three Models developed for the study are represented in Table (4). Model 1 is significant at 0.01 level and 
has an explanatory power (R2 is 0.086 and adjusted R2 0.067). The t statistics with the largest absolute values are 3.170 and -2.808 (p-value < 0.01 ), which relate to board structure composed index BOARD and firm size respectively. As expected, the board structure composed index has a positive effect and firm size has a negative effect on firm performance. The overall conclusion from testing Model 1, board structure composed index BOARD and firm size have a comparable degree of importance in the model. However, PREF in Model 2 is insignificant with OWNER. Thus results suggest that firm performance over the period 2009-2014 was not associated with ownership structure.

According to Model 3, the model is highly significant at 0.01 level and has an explanatory power (R2 is 0.091 and adjusted R2 0.071). The t statistics with the largest absolute values are 3.344 and -2.804 (p-value $<0.01$ ), which relate to Governance quality composed index GOV and firm size respectively. Therefore, GOV and SIZE have a comparable degree of importance in Model 3. Aside from analyzing the relation between PERF and GOV, Model 3(a) analyzes the relation between PERF and governance components in a separate model. Model 3(a) is highly significant at the 0.01 level and has a R2 of 0.329 and adjusted R2 of 0.296 . Tolerance values are calculated using (1-R2) for each variable and are presented in Table (5). Since all values are more than 0.10 , there is no issue of multi-colinearity between the independent variables (Menard, 1995). Also, all of the variance inflation factors (VIF) for the independent variables are less than 10, suggesting that there is no multi-colinearity between these variables (Myers, 1990).

The results of empirical testing of the model indicate that, as predicted, PRIV, INST and ManOwn are highly significantly positive at the 0.01, also SIZE is highly significantly negative at the 0.01 level. Contrary to expectations, OWCO is highly significantly negative at the 0.01 level and BSIZE is highly significantly positive at the 0.01 level. Further, BINDEP and CA are slightly significantly negative and at the 0.10 level. Dual, DBEQ, and LEV are not significantly correlated with PERF. The overall conclusion from testing Model 3(a), all variables except CEO/Chair Duality, debt to equity, leverage and CA have a comparable degree of importance in the model and make the strongest unique contribution to explaining firm performance determination.

Models 3(b - d) analyze the impact of individual firm governance components on each of the three performance dimensions explored in this study: ROA, ROE, and Tobin's Q. The objective is to explore the 
governance component that drives specific performance dimensions. To test these effects, this study repeats the empirical testing of Model 3(a) in three different OLS regression models titled Models $3(b-d)$, after replacing the dependent variable PERF in each model with one of the performance dimensions. The F-statistics on all three Models 3(b-d) are more than 5 and significant at the 0.01 level and have high explanatory powers. R2 for the models are $0.446,0.259$, and 0.233 , respectively and adjusted $\mathrm{R} 2$ are 0.419 , 0.233 , and 0.196 , respectively.

Model 3(b) in Table (5) presents the beta coefficients for the independent variables. The $t$ statistics with the largest absolute values are 5.983, 5.881, $5.183,-3.256,-3.213$, and 2.016 ( $\mathrm{p}$-value $<0.01$ ), which related to institutional ownership, board size, private ownership, ownership concentration, firm size, and director's ownership respectively. ROA is significantly positively associated with institutional ownership, board size, private ownership, and top management ownership. Moreover, ROA is highly significantly negatively associated with ownership concentration, and firm size. This indicates that the six variables have a comparable degree of importance in the model. In other words, they make the strongest unique contribution to explaining firm performance.

The results of empirical testing of Model 3(c) indicate that ROE is significantly positively related to INST, BSIZE, and PRIV. Also ROE is significantly negatively related to BINDEP, OWCO, CA and SIZE.

However, it is insignificantly positively affected by Dual. The results of empirical testing of Model 3(d) indicate that Tobin's Q is significantly positively related to ManOwn, INST, and PRIV, and is significantly negatively related to BINDEP, OWCO, and CA. On the other hand, Tobin's $\mathrm{Q}$ is insignificantly negatively affected by BSIZE, DBEQ, and SIZE, but insignificantly positively related to LEV.

The overall conclusion from testing Models 3 (b) through (d) is that governance components have strong effects on all performance dimensions. Institutional ownership, private ownership, and ownership concentration have the strongest effects on the three performance dimensions: ROA, ROE and Tobin's Q. Firm size is influential in explaining the variations in ROA and ROE. Board composition explains variations in ROE and Tobin's Q. While board size positively affects ROA and ROE, it does not affect Tobin's Q. ManOwn has a strong influence on Tobin's Q and a medium influence on ROA but it has a marginal influence on ROE. 


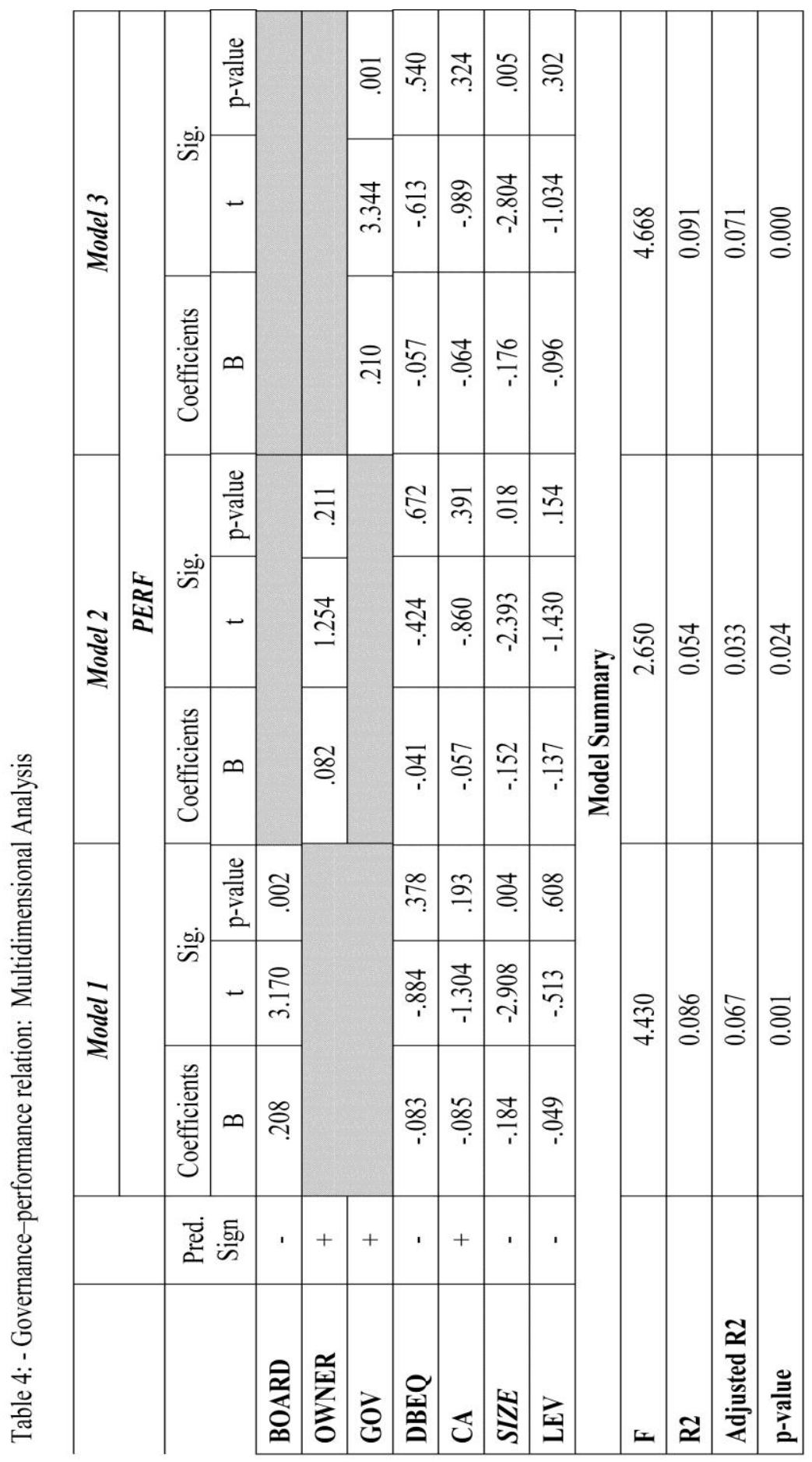




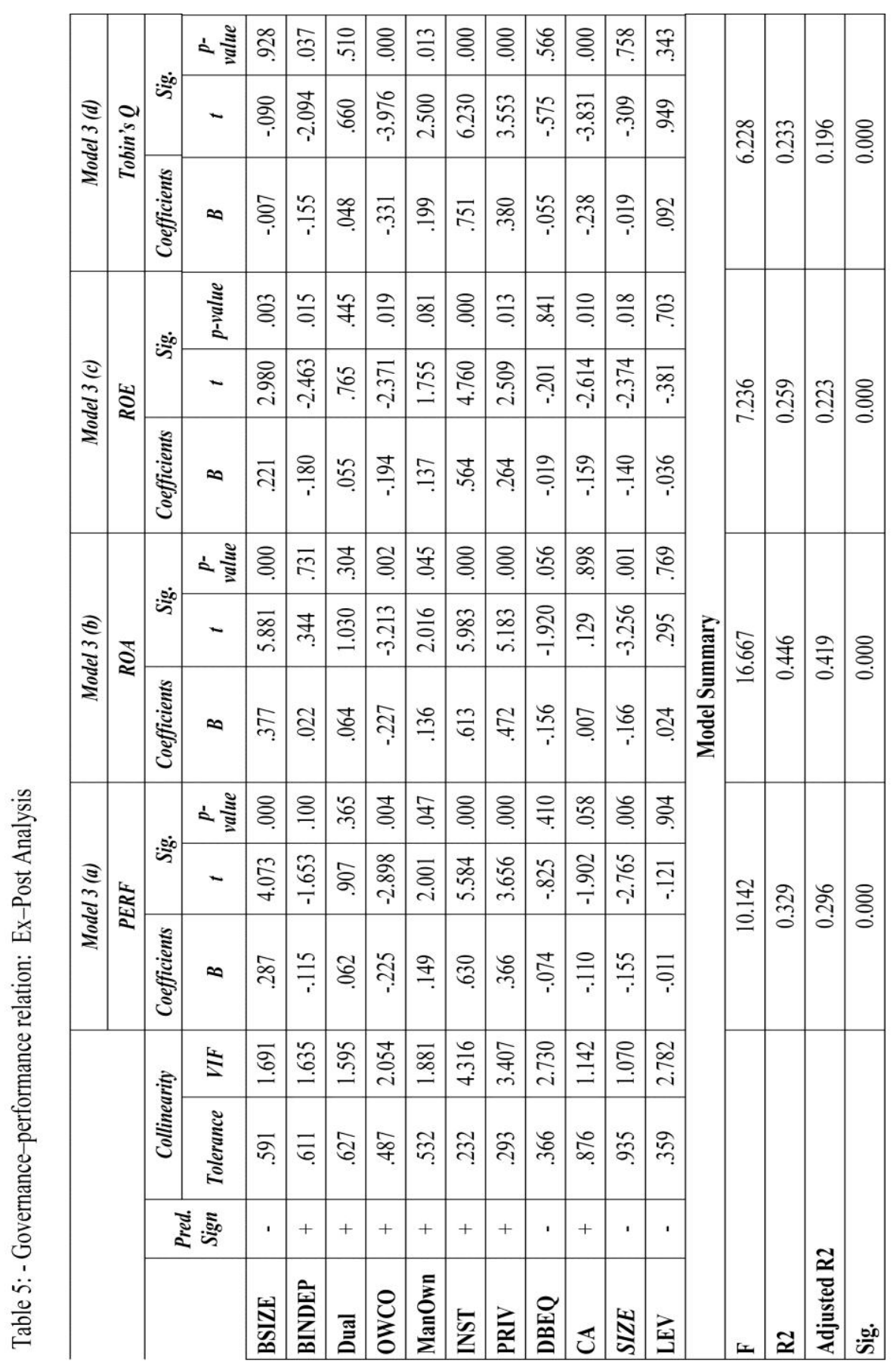




\section{5- Conclusion}

The primary contribution to the literature is that, instead of considering just a single measure of governance and performance, this study considers seven different governance and three performance measures. Governance is measured in this study as a multidimensional composite index comprised of board structure characteristics and ownership structure characteristics. The composite index, GOV, represents the overall governance quality. Moreover, the study measures performance through an integrated multilevel including return on assets "ROA", return on equity "ROE", and Tobin's Q. The composite index, PERF, represents the overall firm performance. The empirical results show that: -

1. Governance quality index has high significant positive impact on firm performance index. This finding is compatible with many studies (e.g. Elbannan and Elbannan, 2014; Coles, et al. 2008; Bhagat and Bolton, 2008).

2. The influence of board and ownership structures index on performance components are examined separately. The empirical results showed that board structure index has high significant positive influence on firm performance. However, the ownership structure index has insignificant influence on firm performance.

3. The effect of governance index components on performance components is examined separately. Evidence showed that performance is a function of some of the individual governance quality components.

4. Evidence showed that, board size is found to be highly positively significant determinant for PERF, ROA, and ROE; however, it is an insignificant determinant for Tobin's Q. This result is consistent with the resource dependence theory and suggests that larger board size would lead to better corporate performance because of the different skills, knowledge, and expertise brought into boardroom discussion. However, this result is against the findings of Cheng (2008); and Yermack (1996).

5. Further, the results indicate that, board composition proxied by proportion of non-executive directors has marginally significant negative impact on firm performance components. The result showed that increasing number of independent directors on firm board will have a marginally negative effect on accounting and market performance. This result is inconsistent with studies that found no significant relationship between presence of outsiders and firm performance 
(Adams and Mehran, 2012). It contrasted with views emphasizing presence of independent directors on firm board for their ability to mitigate the agency problem and enhance performance due to their diversified experiences and qualification (Eisenhardt, 1989; Fama and Jensen, 1983). In addition, it could be interpreted that firm executives have more access to specific-firm information, knowledge, and more communication with firm employees and aware of their problems, which enable them to stimulate, encourage and enhance employees' performance and productivity through professional trainings, orientations, and compensation schemes.

6. In spite of the strong argument that the positions of CEO and Chairman of the board should be separated in the Egyptian firms to reduce agency cost and mitigate managerial entrenchment, the empirical evidence showed that the relation between CEO/Chairman duality and firm performance is insignificant. Moreover, when analyzing the components of the performance index separately, this study found that duality has no impact on all performance dimensions. This result agreed with Dalton et al. (1999) who found no significant difference between the firms with CEO duality and firm performance. However, this finding is inconsistent with the results of many studies in the literature such as Leighton and Thain (1993); Rechner and Dalton (1991); and Rechner and Dalton (1991) who found a positive relationship between an absence of CEO duality and firm performance. This result could be because of different legal, institutional, and cultural factors operate in Egypt.

7. Regarding ownership structure variables, evidence showed that, institutional ownership and private-firm ownership are found to be associated significantly positively with firm performance. As well, they have high significant impact on firm performance index PERF and on all performance components. This result supports the theoretical expectation and gives support to the results of many studies such as Lakshmi (2009); Farinos et al (2007); and Dewenter and Malatesta (2001).

8. Furthermore, ownership concentration is significant and negatively associated with firm performance. The findings support many scholars who are opponents of concentration of ownership and argue that concentration leads to expropriation of minorities and poor performance (Laeven and Levine, 2009). However, this result against 
the view of ownership concentration is more effective and enhances monitoring and governance (e.g. Shehzad et al., 2010; and Iannotta et al., 2007).

9. Interestingly evidence showed that, managerial ownership is highly determinant of market performance and return on assets but marginally determinant of return on equity. This result is consistent with the studies that argue that larger managerial ownership stimulated asset utilization ratios (Singh and Davidson, 2003).

10. Moreover, empirical evidence showed that capital adequacy, firm size, and leverage are negatively significant determinants for firm performance. This result is against the findings of Naceur and Kandil (2009) who argue that higher capital-to-assets ratios lead to improvement in the performance of the firming sector in Egypt.

The above findings have important implications for researchers, senior policy makers, and corporate boards. Efforts to improve corporate governance should focus on stock ownership of top management since it is positively related to both accounting and market performance. Proponents of board independence should note with caution the negative relation between board independence and firm performance. Hence, if the purpose of board independence is to improve performance, then such efforts might be misguided. This study has policy implications for both the Cairo Stock Market and for other emerging economies. It should be guided by continuous research and data analysis. Future research should be conducted taking into account more corporate governance variables such as the existence of an audit committee, voting coalitions, product-market competition, and other hidden cultural factors. Additional research might also be directed towards the effect of corporate governance mechanisms on the corporate performance of Egyptian firms using larger samples and longer time series.

\section{References}

Adams, R. B., \& Mehran, H. (2012), Bank board structure and performance: Evidence for large bank holding companies. Journal of Financial Intermediation, Vol. 21 No. 2, pp. 243-267.

Agrawal, A. \& Knoeber, C. (1996), Firm performance and mechanisms to control agency problems between managers and shareholders, Journal of Financial and Quantitative Analysis, Vol. 31 No. 3, pp. 337-97. 
Ahuja, G. \& Majumdar, S.K. (1998), An Assessment of the Performance of Indian State-Owned Enterprises, Journal of Productivity Analysis, Vol. 9 No. 2, pp. 113-132.

Al-Najjar, B. \& Hussainey, K. (2009), The association between dividend payout and outside directorships, Journal of Applied Accounting Research, Vol. 10 No. 1, pp. 4-19.

Bae, K., Baek, J., Kang, J. \& Liu, W. (2012), Do Controlling Shareholders' Expropriation Incentives imply a Link between Corporate Governance and Firm Value? Theory and Evidence, Journal of Financial Economics, Vol. 105 No. 2, pp. 412-435.

Barber, B., \& Lyon, J. (1996), Detecting abnormal operating performance: The empirical power and specification of test statistics, Journal of Financial Economics, Vol. 4 No. 3, pp. 359-399.

Bebchuk, L.A. \& Weisbach, M.S. (2010), The state of corporate governance research, Review of Financial Studies, 23 No. 3, pp. 939-961.

Berle, A. \& Means, G. (1932), The Modern Corporation and Private Property. Macmillan, New York.

Bhagat, S. \& Bolton, B. (2008), Corporate governance and firm performance, Journal of Corporate Finance, Vol. 14 No. 3, pp. 257-273.

Bhagat, S., Black, B. (2002), The non-correlation between board independence and long term firm performance, Journal of Corporation Law, 27 No. 2, pp. 231-274.

Boyd, B. K. (1995), CEO Duality and Firm Performance: A Contingency Model, Strategic Management Journal, Vol. 16 No. 4, pp. 301-312.

Brown, L. D. \& Caylor, M. L. (2004), Corporate Governance and Firm Performance, https://papers.ssrn.com/sol3/papers.cfm?abstract_id=586423 (accessed 12 January 2016).

Brown, L.D. \& Caylor, M.L. (2006), Corporate governance and firm valuation, Journal of Accounting and Public Policy, Vol. 25 No. 4, pp. 409-434.

Capozza, D. R. \& Seguin, P. J. (2002), Inside Ownership, Agency Costs and Equity Valuation: Evidence from REITs, online (accessed 21 April 2016). https://pdfs.semanticscholar.org/fe7f/ee29943f8677a39f9155bb41ba5a05b be30a.pdf

Chen, Z., Cheung, Y. L., Stouraitis, A., \& Wong, A. (2005), Ownership concentration, firm performance, and dividend policy in Hong Kong, Pacific-Basin Finance Journal, Vol. 13 No. 4, pp. 431-449 
Cheng, S. (2008), Board size and variability of corporate performance, Journal of Financial Economics, Vol. 87 No. 2, pp. 157-176.

Chiang, H. (2005), An Empirical Study of Corporate Governance and Corporate Performance. Journal of American Academy of Business, Vol. 6 No. 1, pp. 95-101.

Chin, T., Vos, E. \& Casey, Q. (2004), Levels of ownership structure, board composition and board size seem unimportant in New Zealand, Corporate Ownership and Control, Vol. 2 No. 1, pp. 119-28.

Coles, J. \& Hesterly, W. (2000), Independence of the Chairman and Board Composition: Firm Choices and Shareholder Value, Journal of Management, Vol. 26 No. 2, pp. 195-214.

Coles, J. L., Daniel, N. D. \& Naveen, L. (2008), Boards: Does one size fits all, Journal of Financial Economics, Vol. 87 No. 2, pp. 329-356.

Daft, R. (2006), Organisation Theory and Design. New York: South-Western College.

Daily, C.M. and Dalton, D.R. (2004), Boardroom myths: reconciling prescription and research guidance, Handbook of Business Strategy, Vol. 5 No. 1, pp. 15-18.

Dalton, D.R, Johnson, J.L \& Ellstrand, A.E (1999), Number of directors and financial performance: A meta-analysis, Academy of Management Journal, Vol. 42 No. 6, pp. 674-686

Damodaran, A. (2007), Return on Capital (ROC), Return on Invested Capital (ROIC) and Return on Equity (ROE): Measurement and Implications, http://pages.stern.nyu.edu/ adamodar/pdfiles/papers/returnmeasures.pdf (accessed 22 June 2016).

Dehaene, A., Vuyst, V.D. \& Ooghe, H. (2001), Corporate performance and board structure in Belgian companies, Long Range Planning, Vol. 34 No. 3, pp. 383-398.

Del Guercio, D., \& Hawkins, J. (1999), The motivation and impact of pension fund activism, Journal of Financial Economics, Vol. 52 No. 3, pp. 293340.

Demsetz, H. \& Lehn, K. (1985), The structure of corporate ownership: Causes and consequences, Journal of Political Economy, Vol. 93 No. 6, pp. 11551177.

Dewenter, K. L. \& Malatesta, P. H. (2001), State - Owned and Privately Owned Firms: An Empirical Analysis of Profitability, Leverage, and Labor Intensity, American Economic Review, Vol. 91 No. 1, pp. 320-334. 
Eisenberg, T., Sundgren, S. \& Wells, M. T. (1998), Larger board size and decreasing firm value in small firms, Journal of Financial Economics, Vol. 48 No. 1, pp. 35-54.

Eisenhardt, K. M. (1989), Agency Theory: An Assessment and Review, Academy of Management Review, Vol. 14 No. 1, pp. 57-74.

Elbannan M. A. \& Elbannan M. A., (2014), Corporate Governance and Accounting Performance: A Balanced Scorecard Approach, Accounting and Finance Research, Vol. 3 No. 2, pp. 60-76.

Fama, E.F. \& Jensen, M.C. (1983), Separation of Ownership and Control, Journal of Law and Economics, 26: 301- 325.

Fama, E.F. (1980), Agency problems and the theory of the firm, Journal of Political Economy, Vol.88: 288-307.

Farinos, J. E., Garcia, C. J. \& Ibanez, A. M. (2007), Operating and Stock Market Performance of State-Owned Enterprise Privatization, International Review of Financial Analysis, Vol.16 No. 4, pp. 367-389.

Farooqi, J., Harris, O. \& Ngo, T. (2014), Corporate Diversification, Real Activities Manipulation, and Firm Value, Journal of Multinational Financial Management, Vol. 27 No. c, pp. 130-151.

Filatotchev, I., Jackson, G., \& Nakajima, C. (2013), Corporate governance and national institutions: A review and emerging research agenda. Asia Pacific Journal of Management, Vol. 30 No. 4, pp. 965-986.

Finkelstein, S., \& D'Aveni, R. A. (1994), CEO Duality as a Double-Edged Sword: How Boards of Directors Balance Entrenchment Avoidance and Unity of Command. Academy of Management, Vol. 37 No. 5, pp. 10791108.

Goddard, J., Molyneux, P. \& Wilson, J. (2004), The profitability of European banks: A cross-sectional and dynamic panel analysis, The Manchester School, Vol. 72 No. 3, pp. 363-81.

Gompers, P.A., Ishii, J.L. \& Metrick, A. (2003), Corporate governance and equity prices, Quarterly Journal of Economics, Vol. 118 No. 1, pp. 107155. 
Grossman, S. \& Hart, O.D. (1983), An analysis of the principal-agent problem. Econometrica, Vol. 51 No. 1, pp. 7-45.

Han, K.C. \& Suk, D.Y. (1998), The effect of ownership structure on firm performance: additional evidence, Review of Financial Economics, Vol. 7 No. 2, pp. 143-55.

Hermalin, B. \& Weisbach, M. (2003), Boards of directors as an endogenously determined institution: a survey of the economic evidence, Economic Policy Review, Vol. 9 No. 1, pp. 7-26.

Iannotta, G., Nocera, G. \& Sironi, A. (2007), Ownership Structure, Risk and Performance in the European Banking Industry, Journal of Banking Finance, Vol. 31 No. 7, pp. 2127-2149.

Jensen, M \& Meckling, W. (1976), Theory of the firm: managerial behavior, agency costs and capital structure, Journal of Financial Economics, Vol. 3 No. 4, pp.11- 25.

Jensen, M. C. (1993), The Modern Industrial Revolution, Exit and the Failure of Internal Control Systems, Journal of Finance, Vol. 48 No. 3, pp. 831880.

Jensen, M., (1986), Agency costs of free cash flow, corporate finance, and takeovers, American Economic Review, Vol. 76: No. 2, pp. 323-329.

Jiraporn, P., Kim, J.C., Kim, Y.S., \& Kitsabunnarat, P. (2012), Capital structure and corporate governance quality: Evidence from the Institutional Shareholder Services (ISS), International Review of Economics and Finance, Vol. 22 No. 1, pp. 208-221.

Johnson, J. L., Daily, C. M., \& Ellstrand, A. E. (1996), Boards of Directors: A Review and Research Agenda, Journal of Management, Vol. 22 No. 3, pp. 409-438.

Kayhan, A, \&Titman, S. (2007), Firms' histories and their capital structures, Journal of Financial Economics, Vol. 83 No. 1, pp. 1-32.

Kiel, G. C., \& Nicholson, G. J. (2003), Board Composition and Corporate Performance: How the Australian Experience Informs Contrasting Theories of Corporate Governance, Corporate Governance An International Review, Vol. 11 No. 3, pp. 189-205. 
Kim, E. H. \& Lu, Y. (2011), CEO ownership, external governance, and risktaking, Journal of Financial Economics, Vol. 102 No. 2, pp. 272-292.

Klapper, L. and I. Love. 2002. "Corporate Governance, Investor Protection, and Performance in Emerging Markets", World Bank Policy Research Working Paper No. 2818. Washington, D.C.: World Bank.

Kole, S. R. \& Mulherin, H. J. (1997), The Government as a Shareholder: A case from the United States, The Journal of Law and Economics, Vol. 40 No. 1, pp. 1-22.

La Porta, R., F. Lopez-de-Silanes, A. Shleifer, and R. Vishny. (1997) "Legal Determinants of External Finance", Journal of Finance, Vol. 52, No. 3, pp. 1131-1150.

Laeven, L.A., \& Levine, R. (2009), Bank governance, regulation and risk taking, Journal of Financial Economics, Vol. 93 No. 2, pp. 259-275.

Lakshmi, K. (2009), Ownership structure and capital structure: evidence from Indian firms, Working paper, http://ssrn.com/abstract=1344113 (accessed 3 March 2016).

Langton, N., \& Robbins, S. P. (2007), Organizational Behavior: Concepts, Controversies, Applications. Toronto: Prentice Hall.

Leighton, D. R., \& Thain, D. H. (1993), Selecting New Directors, Business Quarterly, Vol. 57 No. 4, pp. 16-26.

Lemmon, M.L. \& Lins, K.V. (2003), Ownership structure, corporate governance, and firm value: Evidence from the East Asian financial crisis, The Journal of Finance, Vol. 58 No. 4, pp. 1445-1468.

Levine, R. (2004), Finance and Growth: Theory and Evidence, Working Paper 10766 http://www.nber.org/papers/w10766.pdf (accessed 21 April 2016).

Lien, Y.-C. \& Li, S. (2013), Does Diversification add Firm Value in Emerging Economies? Effect of Corporate Governance, Journal of Business Research, Vol. 66: No. 6, pp. 2425-2430.

Liljeblom, E. \& Löflund, A. (2005), Determinants of International Portfolio Investment Flows to a Small Market: Empirical Evidence, Journal of Multinational Financial Management, Vol. 15 No. 3, pp. 211-233.

Lin, C.H. \& Shiu, C.-Y. (2003), Foreign Ownership in the Taiwan Stock Market - An Empirical Analysis, Journal of Multinational Financial Management, Vol. 13: No. 1, pp. 19-41. 
Mace, M. L. G. (1971), Directors: Myth and Reality, Boston: Harvard Business School Press.

Macey, J., \& O'Hara, M. (2003), The corporate governance of banks, Federal Reserve Bank of New York Economic Policy Review, Vol. 9 No. 1, pp. 91107.

Mallette, P. \& Fowler, K.L. (1992), Effects of board composition and stock ownership on the adoption of poison pills, Academy of Management Journal, Vol. 35: No. 5, pp. 1010-1035.

Maug, E. (1998), Large Shareholders as Monitors: Is there a trade-off between liquidity and control? Journal of Finance, Vol. 53 No. 1, pp. 65-98.

Menard, S. (1995). Applied logistic regression analysis, Sage University Paper Series on Quantitative Applications in the Social Sciences, Thousands Oaks, CA: Sage.

McConnell, J. \& H. Servaes (1990), Additional evidence on equity ownership and corporate value, Journal of Financial Economics, Vol. 27 No. 2, pp. 595-612.

Myers, R. (1990), Classical and Modern Regression with Applications, Boston, MA: Duxbury.

Naceur, S. B. \& Kandil, M. (2009). The impact of capital requirements on banks' cost of intermediation and performance: The case of Egypt, Journal of Economics and Business, Vol. 61 No. 1, pp. 70-89.

Nguyen, T., Locke, S. \& Reddy, K. (2015), Does boardroom gender diversity matter? Evidence from a transitional economy, International Review of Economics and Finance, Vol. 37 No. 2, pp. 184-202.

Norburn, D., \& Grinyer, P. H. (1974), Directors without Direction, Journal of General Management, Vol. 1 No. 2, pp. 37-48.

Omran, M. (2004), The Performance of State-Owned Enterprises and Newly Privatized Firms: Does Privatization really matters, World Development, Vol. 32 No. 6, pp. 1019-1041.

Pearce, J. A., \& Zahra, S. A. (1992), Board Composition from a Strategic Contingency Perspective. Journal of Management Studies, Vol. 29 No. 4, pp. 411-438.

Pfeffer, J., \& Salancik, G. (1978), The External Control of Organizations, A Resource Dependence Perspective. New York: Harper and Row. 
Pham, P.K., Suchard, J.A. \& Zein, J. (2011), Corporate governance and alternative performance measures: Evidence from Australian firms. Australian Journal of Management, Vol. 36 No. 3, pp. 371-386.

Rechner, P. L., \& Dalton, D. R. (1991), CEO Duality and Organizational Performance: A Longitudinal Analysis, Strategic Management Journal, Vol. 12 No. 2, pp. 155-160.

Rhoades, D. L., Rechner, P. L., \& Sundaramurthy, C. (2001), A Meta-analysis of Board Leadership Structure and Financial Performance: Are "Two Heads Better than One"? Corporate Governance: An International Review, Vol. 9 No. 4, pp. 311-319.

Schultz, E.L., Tan, D.T. \&Walsh, K.D. (2010), Endogeneity and the corporate governance-performance relation. Australian Journal of Management, Vol. 35 No. 2, pp. 145-163.

Shehzad C.T, De Haan, J., \& Scholtens, B. (2010), The impact of bank ownership concentration on impaired loans and capital adequacy, Journal of Banking and Finance, Vol. 34 No.2, pp. 399-408.

Shleifer, A. \& Vishny, R.W. (1986), Large shareholders and corporate control. Journal of Political Economy, Vol. 94 No. 3, pp. 461-488.

Singh, M., \& Davidson, W. N. (2003), Agency Cost, Ownership Structure and Corporate Governance Mechanisms, Journal of Banking and Finance, Vol. 27 No. 5, pp. 793-816.

Smith, M. (1996), Shareholder activism by institutional investors: Evidence from CalPERS, Journal of Finance, Vol. 51 No. 1, pp. 227-252.

Toal, U. L. \& Ruenzi, S. (2014), CEO Ownership, Stock Market Performance, and Managerial Discretion, Journal of Finance, Vol. 69 No. 3, pp. 10131050

Yabei, H., \& Izumida, S. (2008), Ownership concentration and corporate performance: A causal analysis with Japanese panel data, Corporate Governance: An International Review, Vol. 16 No. 4, pp. 342-358.

Yermack, D. (1996), Higher market valuation of companies with a small board of directors, Journal of Financial Economics, Vol. 40 No. 2, pp. 185-211.

Yu, M. (2013), State Ownership and Firm Performance: Empirical Evidence from Chinese Listed Companies, China Journal of Accounting Research, Vol.6 No. 2, pp.75-87. 